\title{
АКТУАЛЬНІ АСПЕКТИ ПОЗАШКІЛЬНОЇ ОСВІТИ: ЗАРУБІЖНИЙ ДОСВІД
}

\author{
Ворона Л. I. \\ кандидат педагогічних наук, \\ доиент кафедри педагогіки \\ Луганський наџіональний університет імені Тараса Шевченка \\ пл. Гоголя, 1, Старобільськ, Луганська область, Україна \\ orcid.org/0000-0001-9878-6547 \\ voronali@ukr.net
}

\author{
Ключові слова: система \\ позашкільної освіти, \\ позашкільна освіта, \\ неформальна освіта, \\ додаткова освіта, \\ позашкільний навчальний \\ заклад, мережа позашкільних \\ навчальних закладів.
}

Стаття присвячена вивченню зарубіжного досвіду функціонування позашкілля як унікальної виховної системи підростаючого покоління у вільний від навчання час у різних країнах світу. Автор акцентує увагу на необхідності вдосконалення системи позашкільної освіти та ії трансформації в межах Нової української школи, бо саме на позашкільну освіту покладена важлива місія у вихованні учнівської молоді. Виховний процес, як наголошується в Концепції Нової української школи, має стати невід'ємною складовою частиною всього освітнього процесу, проходячи через навчальну діяльність, систему позакласної та позашкільної роботи. Зазначено, що позашкільна освіта повинна стати основою для виховання особистості і має для цього найбільш сприятливе середовище добровільність навчання, вільний вибір напряму діяльності. У системі позашкілля вагому роль відіграє виховна робота як організований процес, який спрямований на формування всебічно і гармонійно розвиненої особистості. Наголошено, що умовах формування Нової української школи завданням виховання та навчання в закладах позашкільної освіти є створення таких умов, за яких може розвинутися людина європейського мислення, тому дослідження системи позашкільної освіти в різних країнах $є$ актуальним для вітчизняної педагогічної науки. Нині проблема організації вільного від навчання часу дітей набула особливої актуальності i визначає молодіжну політику багатьох країн світу. У статті проаналізовано й узагальнено досвід організації діяльності та функціонування закладів позашкільної освіти зарубіжних країн, встановлено шляхи імплементацій кращих практик у систему позашкілля України. Позашкільна освіта різних країн відрізняється назвою, змістом, структурою, але має спільну мету - організувати діяльність дітей у вільний час, забезпечити реалізацію потреб, запитів та інтересів учнів у самореалізації, соціалізації, включення в суспільні відносини, розвивати творчі здібності у сфері культури, мистецтва, техніки, туризму та краєзнавства, екології, спорту, наукових знань. 


\title{
CURRENT ASPECTS OF EXTRACURRICULAR EDUCATION: FOREIGN EXPERIENCE
}

\author{
Vorona L. I. \\ Candidate of Pedagogical Sciences, \\ Associate Professor at the Department of Pedagogy \\ Luhansk Taras Shevchenko National University \\ Gogol sq., 1, Starobilsk, Luhansk region, Ukraine \\ orcid.org/0000-0001-9878-6547 \\ voronali@ukr.net
}

Key words: system of outof-school education, out-ofschool education, informal education, additional education, out-of-school educational establishment, network of out-of-school educational establishments.

\begin{abstract}
The article is devoted to the study of foreign experience of the functioning of extracurricular activities as a unique educational system of the younger generation in their free time, in different countries. The author emphasizes the need to improve the system of out-of-school education and its transformation within the New Ukrainian School, because out-of-school education has an important mission in the education of young students. The educational process, as emphasized in the Concept of the New Ukrainian School, should become an integral part of the entire educational process, going through educational activities, the system of extracurricular and extracurricular activities. It is noted that out-of-school education should become the basis for the education of the individual and has the most favorable environment for this - voluntary education, free choice of direction. In the extracurricular system, an important role is played by educational work as an organized process, which is aimed at forming a comprehensively and harmoniously developed personality. It is emphasized that the conditions of formation of the New Ukrainian school, the task of education and training in out-of-school education is to create such conditions under which a person of European thinking can develop, so the study of out-of-school education in different countries is relevant for domestic pedagogical science. Today, the problem of organizing children's free time has become especially relevant and determines the youth policy of many countries. The article analyzes and summarizes the experience of organizing the activities and functioning of out-of-school educational institutions of foreign countries, identifies ways to implement best practices in the out-of-school system of Ukraine. Extracurricular education in different countries differs in name, content, structure, but have a common goal - to organize children's leisure activities, ensure the needs, requests and interests of students in self-realization, socialization, inclusion in public relations, develop creative abilities in culture, art, technology, tourism and local lore, ecology, sports, scientific knowledge.
\end{abstract}

Постановка проблеми. Держава, яка дбає про своє майбутнє, яка зацікавлена у своєму розвитку, економічному зростанні та процвітанні робить усе, щоб не втратити підростаюче покоління, дбаючи про вільний час учнівської молоді. Осередками піклування дітей у позаурочний час є заклади позашкільної освіти. Проблема цілеспрямованої організації вільного часу дітей і молоді набула особливої актуальності і визначає молодіжну політику багатьох країн. В умовах змін і реформ державна політика національної освітньої системи повинна використовувати кращий досвід зарубіжних країн, бо значення позашкільної освіти в освітній системі країни очевидне. Позашкільна освіта - це важливий спектр системи освіти в Україні. Проблематикою сучасної освітньої галузі в Україні $\epsilon$ шляхи підвищення якості діяльності та функціонування закладів позашкільної освіти як осередків надання освітніх послуг дітям у позаурочний час. Сьогодні проблема організації вільного часу дітей набула особливої актуальності та визначає молодіжну політику багатьох країн світу. Досвід функціонування закладів позашкільної освіти інших країн цікавий і вартий уваги для України. 
Аналіз останніх досліджень i публікацій. Питання розвитку позашкільної освіти висвітлювали у своїх працях Т.І. Сущенко, В.В. Вербицький, Г.П. Пустовіт, О.В. Биковська, Л.І. Ковбасенко, Л.В. Тихенко. Особливості позашкілля у зарубіжних країнах досліджували у своїх працях українські вчені О. Биковська, Н. Савченко, В. Стрижалковська, I. Петрова, Р. Науменко, В. Давидова, О. Компанієць та інші.

Мета дослідження: проаналізувати й узагальнити досвід організації діяльності та функціонування закладів позашкільної освіти зарубіжних країн та встановити шляхи імплементацій кращих практик у систему позашкілля України.

Виклад основного матеріалу. Позашкільна освіта різних країн відрізняється назвою. У європейських країнах в освітній системі використовуються поняття: «неформальна освіта» (англ. - non-formal education), «заклади позашкільного виховання», (польськ. - placowki wychowania pozaszkolnego), «додаткова освіта» (рос. - дополнительное образование), центри вільного часу (словацьк. - centrum vol'neho casu) тощо [5]. У Міжнародній освітянській системі використовується тільки один термін - «неформальна освіта». Нині немає єдиного визначення терміна «неформальна освіта», кожен дослідник розглядає це поняття по-своєму, але у визначення вкладена одна й та сама суть. Особливістю неформальної освіти $\epsilon$ те, що в такій освіті немає стандартних освітніх програм. Аналіз визначень термінів «неформальна освіта» дає можливість зробити висновок, що це організована та цілеспрямована навчальна діяльність, яка здійснюється за межами закладів формальної освіти, спрямована на задоволення різноманітних освітніх потреб. Формальна освіта $\epsilon$ добровільною, доповнює формальну освіту, забезпечує засвоєння знань, умінь і навичок, проте не надає легалізованого сертифікату. Позашкільні заклади відрізняються змістом, структурою, але мають спільну мету організувати діяльність дітей у вільний час, забезпечити реалізацію потреб, запитів та інтересів учнів у самореалізації, соціалізації, включення в суспільні відносини, розвивати творчі здібності у сфері культури, мистецтва, техніки, туризму та краєзнавства, екології, спорту, наукових знань тощо [4].

Офіційно позашкільна освіта функціонує в багатьох країнах світу. 3 метою досягнення взаєморозуміння в освітньому просторі Свропи представники Чехословаччини, Франції, Нідерландів та України у 1991 році ухвалили спільне рішення про створення Європейської Асоціації установ вільного часу дітей і молоді (EAICY), штаб-квартира якої знаходиться у м. Прага. Необхідною умовою входження держав до світової та європейської спільноти є застосування та дотримання у правовій сфері країн міжнародно-правових документів. У ст. 31 Конвенції ООН про права дитини визначено, що «держави-сторони поважають і заохочують права дитини на всебічну участь у культурному та творчому житті, сприяють наданню відповідних і рівних можливостей для культурної і творчої діяльності, дозвілля і відпочинку [2]. В основу діяльності Асоціації покладені принципи демократії, гуманізму, свободи та рівності. У Статуті проголошені ідеї, прийняті $\mathrm{OOH}$ і ЮНЕСКО щодо роботи 3 дітьми та юнацтвом. Головними документами Асоціації є Декларація прав дитини 1959 р. і конвенція ООН про права дитини 1989 р. Основна мета роботи Асоціації сприяти здоровому, всебічному розвитку дітей і молоді за допомогою багатосторонніх контактів, семінарів, конференцій, конкурсів, фестивалів, реалізації спільних програм і проектів [5].

Позашкільне виховання в Білорусії $€$ частиною державної політики країни. Додаткова освіта в Білорусії входить до системи освіти як іiї складник та спрямована на розширення можливостей в інтелектуальному, естетичному, моральному та фізичному розвитку особистості під час отримання основної освіти, поглиблення професійної компетентності, а також на вирішення завдань кадрового забезпечення всіх сфер соціального-економічної діяльності (ст. 7 Закону Республіки Білорусь «Про освіту»).

Позашкільна освіта активно підтримується i розвивається на державному рівні в Болгаpiï. У країні успішно функціонує Національний Палац дітей Болгарії. На місцевому рівні працює розгалужена мережа закладів позашкільної освіти. У позашкільних закладах найбільше створено гуртків художньої творчості (танці, фольклор, декоративно-прикладне мистецтво), працюють гуртки спортивного, екологічного напрямів. Велика підтримка й увага приділяється гурткам технічної творчості - судномоделювання, автомоделювання, авіамоделювання. Держава забезпечує та враховує відвідування однією дитиною трьох гуртків одночасно, це забезпечує всебічний розвиток особистості. Загалом є багато спільного в позашкільній освіті Болгарії та України [7].

Франція унікальна у сфері додаткової освіти. У країні є відведений день (середа - за давньою традицією день сімейного виховання), коли батьки зобов'язані $з$ дитиною відвідувати гуртки. Діти у Франції навчаються чотири дні. Середа як вихідний день відведена для того, щоб діти відвідали музеї, театри, кінотеатри, концерти. Для дітей у цей день пропонуються різноманітні дитячі програми, презентації, прем'єри, і батьки зобов'язані організувати повноцінне дозвілля своєї дитини. Для дітей, чиї батьки працюють по середах, 
у країні працюють спеціальні центри дозвілля, які фінансуються муніципалітетом або самі заробляють собі на життя. Для сімей, що не можуть заплатити за навчання в дорогих гуртках і спеціалізованих музичних і спортивних школах, держава бере на себе більшу частину оплати дитячих захоплень. В усіх інших випадках батьки платять за додаткові освітні послуги [8].

Основу організаційної структури позашкільної освіти Польщі становлять заклади позашкільного виховання. Основними типами закладів позашкільного виховання є: центри позашкільної роботи, молодіжні будинки культури, міжшкільні спортивні центри, дитячі майданчики, палаци молоді, центри освіти, молодіжні астрономічні обсерваторії тощо. Організація позашкільної освіти здійснюється за такими напрямами, як художній, технічний, науковий, спортивний. Мета діяльності позашкільних установ - допомогти школам в організації вільного часу дітей та молоді [1].

У Литві зареєстровано понад 2000 програм неформального виховання дітей i понад 900 нових надавачів послуг. Для неформального виховання використовуються нетрадиційні середовища - парки, музеї, художні майстерні, і позашкільна діяльність стає ближчою до дітей. У Литві за кожну дитину гурток, секція чи інша установа, яку вона відвідує, отримує кошти, що дає змогу залучити нових провайдерів, приватні, неурядові організації, ініціативних людей, зацікавлених у розвитку неформальної освіти. Таким чином, починається конкуренція, що сприяє підвищенню якості позашкільної освіти та кількості охоплених дітей. Головний принцип литовської моделі «гроші йдуть за дитиною», тобто фінансуються реальні діти, які займаються у студіях, гуртках i секціях. Участь у них є добровільною, отже, діти не прийдуть туди, якщо їм буде нецікаво. У Литві відкриваються гуртки відповідно до запитів дітей (IT-технології, робототехніка, іноземні мови) [9].

Сучасне американське позашкілля орієнтоване на формування у дітей соціальної поведінки та збереження їхнього здоров'я. У США є 65 програм позашкільної освіти. Навчальні програми мобільні, формуються відповідно до потреб, пріоритетів, цілей дітей і молоді та орієнтовані на результат. У позашкільній навчальній програмі визначено головні цілі: виробити навички і компетентності, запобігти проявам негативних явищ, сприяти зменшенню агресії, адаптації вихованців до різних ситуацій, підвищенню академічної успішності. Позашкільна освіта в Америці спрямована на позитивний розвиток дитини, пожвавлення iіi соціальної активності, розвиток позитивного ставлення до самого себе. В учнів початкової школи разом із захопленням спортом, розвитком мовлення, удосконаленням навичок читання, вмін- ням швидко реагувати, вирішувати конфлікти, формувати здоровий спосіб життя з'являється і підвищення успішності. Американська позашкільна навчальна програма використовує певні компоненти для досягнення своїх цілей: навчання на основі спеціальних книжок, 5 навчальних діяльностей (дискусії на тему спорту, дослідження, перегляд актуальних мультфільмів, виконання вправ, рухливі ігри), семінари 3 читання, уроки з розвитку навичок комунікацій (вирішення конфліктів, управління гнівом), робота з родиною (проводяться різноманітні сімейні заходи). Позашкільні навчальні заклади США співпрацюють зі школою, громадою, родиною. Партнерство заохочується на федеральному рівні. Американська позашкільна освіта орієнтована на дитину на їі результат. Щоби врахувати потреби дітей, у країні постійно проводять дослідження серед школярів певної вікової категорії [6].

До неформальної освіти для дітей та молоді Ізраїлю належать групи та різноманітні гуртки, що діють при школах та університетах. Більшість із них пов'язані з формуванням у дітей різноманітних соціальних навичок, підтримкою особистості в процесі соціалізації, психічно-емоційними аспектами формування особистості. Значне місце серед молодіжних організацій неформальної освіти займають молодіжні рухи (скаути «Цофім»). В Ізраїлі діти мають можливість здобувати неформальну освіту у спеціалізованих центрах. Креативне навчання з театрального мистецтва, фізики, живопису, математичного мислення, логіки проводять педагоги-реформатори. Навчання в таких центрах відбувається за рахунок певних фондів, які є спонсорами роботи центрів, надаючи їм належне матеріально-технічне оснащення. Навчання в закладах починається відразу після закінчення уроків. Діти мають змогу навчатися гончарної справи, виготовляти вироби 3 дерева або пластику, учителі з ними виконують домашні завдання та грають в ігри. Діти, що беруть участь у таких програмах, цілий день перебувають під наглядом педагогів. Такі програми діють у кожному місті за потреби. Основним завданням неформальної освіти $є$ навчання та виховання дітей із неблагонадійних сімей. Також велика увага приділяється функціонуванню комп'ютерних центрів, які дають можливість учням, що відвідують центри, розвивати дослідницькі вміння. Центри неформальної освіти часто використовують як виставкові зали, де кожен учень може продемонструвати свої персональні досягнення. Система позашкільної освіти Ізраїлю організована для розвитку здібностей, поглиблення знань, виховання кожної дитини. Навчання під супроводом кваліфікованих педагогів має більше прикладний характер [3]. 
У Нідерландах поширені Програми продовженого шкільного дня, які проходять протягом двох місяців. Дітям пропонують взяти участь у театральних, циркових колективах, грати на музичних інструментах, займатися малюванням, спортом, фотографуванням. Кількість видів практичної діяльності залежить від школи і може досягати 25 предметів за один рік навчання.

Цікавим $є$ досвід організації позашкілля в індустріально розвинених азіатських країнах. Навчання в Китаї від початкової школи до вищої є платним, але мережа закладів додаткової освіти повністю безкоштовна і загальнодоступна. Держава надає великого значення розвитку додаткової освіти в країні. Найбільший Палац дитячої творчості в Китаї відвідують більше 3 тисяч дітей iз 30 тематичних модулів та профілів роботи, заробітна плата співробітників закладу прирівнюється до заробітної плати шкільних педагогів. Варто звернути увагу на формування платні педагога позашкільного закладу, яка залежить від кваліфікації працівника, від кількості учнів, що відвідують гурток, та їхніх індивідуальних досягнень на різноманітних змаганнях та конкурсах, а також враховуються відгуки дітей про роботу педагога, які вони записують у спеціальних анкетах. У розвиток позашкільної освіти держава вкладає великі кошти. Постійно збільшується загальнодоступна мережа дитячих палаців творчості та багатопрофільних науково-технічних центрів, дитячих майданчиків для дозвілля, палаців сучасної науки i техніки, інтерактивних павільйонів профорієнтації та підліткових клубів за місцем проживання. Влада КНР зрозуміла, що система додаткової освіти краще від інших забезпечує виховання креативних, самодостатніх громадян, здатних розпочати свою справу, а також і те, що мережа закладів додаткової освіти є надійним засобом профілактики злочинності серед учнівської молоді.

Державна політика стосовно розвитку позашкільної освіти Китаю визначена в документах «Стратегія розвитку освіти в Китаї у XXI ст.» та «Реформи розвитку базової освіти в КНР», для покращення роботи розроблені програми раннього виявлення і підтримки талановитих учнів [8].

Мережа неформальної освіти в Японії зосереджується у школах. За правилами японської системи освіти кожен першокласник зобов'язаний щодня, крім неділі, працювати після уроків в одному з учнівських гуртків за інтересами. 3 усіх запропонованих напрямів учень повинен вибрати або один спортивний, або два творчих гуртки і відвідувати їх протягом усього навчання в школі. Фінансування кожного гуртка залежить від кількості учнів, що відвідують гурток. Тому логічно, що робота гуртка проходить на високому рівні, щоб витримати конкуренцію і зацікавити учня до роботи. На початку навчального року в японських школах проходить незвичайне свято - феєрверк відкритих уроків і рекламних акцій. Організаторами свята $\epsilon$ керівники студій, гуртків та спортивних секцій, які відкрито та чесно борються між собою за майбутніх учнів. Кожен керівник намагається залучити до роботи у своєму гуртку якнайбільше першокласників, влаштовуючи показові заняття залучених до них учнів, що навчаються не один рік і мають певні результати та досягнення. Тих дітей, які не змогли знайти собі заняття за інтересом, об'єднують у гурток «білих ворон». Змінити гурток учням не рекомендують, такі їхні дії будуть засуджені однокласниками і вчителями. Неформальна освіта характерна не тільки для японських шкіл, у місцевих університетах працюють творчі студії та спортивні секції. Більшість із них працюють безкоштовно [8].

Висновки і перспективи подальших розробок. В умовах змін і реформ державна політика національної освітньої системи повинна використовувати кращий досвід зарубіжних країн. У західноєвропейських країнах неформальна освіта $\epsilon$ приватною. Освітні послуги надаються за рахунок батьків, приватних фірм, громадських організацій, різних компаній, результат - надання дійсно якісних послуг. У східноєвропейських країнах переважає концепція розвитку, відповідальність за організацію і функціонування системи неформальної освіти бере на себе уряд країни, цим самим надаючи установам неформальної освіти статус державного закладу. Цікавий для України досвід функціонування позашкілля у Польщі саме тут неформальна освіта найбільше схожа за своїми напрямами, змістом, методами та принципами до системи позашкільної освіти України. Розглянувши організаційні засади діяльності та функціонування закладів позашкільної освіти зарубіжних країн, можна виокремити спільні 3 українським позашкіллям напрями роботи: розвиток партнерства та співпраці між державою, громадськими організаціями, приватними компаніями, педагогами та батьками; посилення державної підтримки позашкілля; розширення мережі позашкільних навчальних закладів. Багато ідей можна перейняти для покращення роботи в закладах позашкільної освіти України. Перспективами використання досвіду зарубіжних країн для розвитку національної системи позашкільної освіти можуть стати: впровадження комплементарного підходу; забезпечення доступності та підвищення якості позашкільної освіти; швидке реагування закладу на потреби вихованців; розвиток громадянського виховання як важливого напряму позашкілля. Перспективи подальших досліджень пов'язані з вивченням позашкільної освіти інших зарубіжних країн. 


\section{ЛІТЕРАТУРА}

1. Биковська О.В. Порівняльний аналіз системи позашкільної освіти України і Польщі. Теоретикометодологічні основи виховання творчої особистості учнів в умовах позашкільних закладів : матеріали наук.-практ. конф. К. : Грамота, 2006, Ч. I. С. 58-72.

2. Конвенція ООН про права дитини. URL: http:/www.un.org.ua/images/documents/3719/convention small final.pdf.

3. Компанієць О. Система неформальної освіти в Iзраїлі URL: http://www.irbis-nbuv.gov.ua/.

4. Науменко Р.А. Позашкільна освіта в Україні та в країнах Європи: порівняльний аспект. URL: http://www.nbuv.gov.ua/e-journals/dutp/2006-2/txts/GALUZEVE\%5C06nraepa .pdf.

5. Позашкільна освіта, 2018: десять перемог. URL: https://www.ukrinform.ua/.../2604864-pozaskilnaosvita-2018-desat- peremog.html.

6. Позашкільна освіта в розвитку держав. Позашкілля. 2016, № 7. С. 4-6.

7. Позашкільна освіта: досвід Болгарії. URL: htts://upmp.nevs.

8. Позашкільна освіта: Китай, Японія і Франція. Позашкілля. 2014, № 8. С. 6-8.

9. Покровськ: новий погляд на позашкілля. URL: htts//www.pokrovsk.citi.

\section{REFERENCES}

1. Bykovska O.V. (2006) Porivnyalnyy analiz systemy pozashkilnoyi osvity Ukrayiny y Polshchi [Bykovskaya OV Comparative analysis of the system of out-of-school education of Ukraine and Poland]. Teoretykometodolohichni osnovy vykhovannya tvorchoyi osobystosti uchniv v umovakh pozashkilnykh zakladiv: materialy nauk.-prakt. konf. K. : Hramota, 2006. Ch. I. S. 58-72.

2. Konventsiya OON (1989) pro prava dytyny [UN Convention on the Rights of the Child]. URL: http://www.un.org.ua/images/documents/3719/ convention_small_final.pdf.

3. Kompaniyets O. (2017) Systema neformalnoyi osvity v Izrayili [Kompaniets O. The system of non-formal education in Israe]. URL: http://www.irbis-nbuv.gov.ua/.

4. Naumenko R.A. (2009) Pozashkilna osvita v Ukrayini ta v krayinakh Yevropy: porivnyalnyy aspect [Naumenko R.A. Extracurricular education in Ukraine and in European countries: a comparative aspect] URL: http://www.nbuv.gov.ua/e-journals/dutp/2006-2/txts/GALUZEVE\%5C06nraepa.

5. Pozashkilna osvita (2018): desyat peremoh [Extracurricular education - 2018: ten victories]. URL: https:// www.ukrinform.ua/.../2604864-pozaskilna-osvita-2018-desat-peremog.html.

6. Pozashkilna osvita v rozvytku derzhav (2016) [Extracurricular education in the development of states] / Pozashkillya. 2016, № 7. S. 4-6.

7. Pozashkilna osvita: dosvid Bolhariyi (2018) [Extracurricular education: the experience of Bulgaria]. URL: htts//upmp.nevs.

8. Pozashkilna osvita (2014): Kytay, Yaponiya i Frantsiya [Extracurricular education: China, Japan and France]. Pozashkillya, 2014, № 8. S. 6-8.

9. Pokrovsk: novyy pohlyad na pozashkillya (2018) [Pokrovsk: a new look at extracurricular activities]. URL: htts//www.pokrovsk.citi. 